\title{
Relationship Between Body Composition, Vertical Jump, 30 M Sprint, Static Strength and Anaerobic Power for Athletes
}

\author{
Nigar Küçc̈kkubaş ${ }^{1}$, Ali Günay $^{2}$, Berkay Löklüoğlu ${ }^{3}$, Berkay Kakil $^{3}$
}

\begin{abstract}
Aim: The purpose of the study is to determine the relationship between body composition, vertical jump, sprint, static strength, and anaerobic power of athletes.

Methods: 19-27 years old (training 2 hours/day, 4 days/week, training at least 4 years) 28 male ( $23.11 \pm 1.71$ years; 1 fitness, 1 mountain climber, 1 swimmer, 15 football, 2 basketball, and 8 tennis players), 19 female ( $21.95 \pm 2.37$ years; 3 Zumba, 1 cross country runner, 5 basketball, 2 football, 6 tennis, and 2 volleyball players) athletes participated voluntarily. Body composition compartments, height, skinfold thicknesses, Vertical Jump and $30 \mathrm{~m}$ sprint by using timer gates were measured. Wingate Anaerobic Test (WAnT) was used to determine peak anaerobic power $\left(\mathrm{WAnT} \mathrm{T}_{\mathrm{PP}}\right)$ and mean anaerobic power $\left(\mathrm{WAnT}_{\mathrm{MP}}\right)$.

Results: There was no significant relationship between fat compartment of body composition and vertical jump or $30 \mathrm{~m}$ sprint performances for male athletes. In addition to that, there were no relationships between the fat compartment and any of the performance parameters of vertical jump, sprinting, WAnT results for female athletes.

Conclusion: Sport specific strength requirements to be discussed for performance determinants have yet been incomplete and versatile research subject. To predict the sport performance, follow-up and performance focused battery should be studied by all affecting parameters such as physiological, neurological, detailed body composition compartments.
\end{abstract}

\section{INTRODUCTION}

Determining the upper limits of sport performance is important in achieving the desired result at any competition. Each \& every sport along with its multiple branches has combinations of factors/needs of aerobic \& anaerobic power, sprint, endurance, strength, and body size with different ratios for peak performance to make a difference (Aouadi et al., 2011; Granier, Mercier B, Mercier J, Anselme \& Prefaut, 1995; Kale, Aşçı, Bayrak, \& Açıkada, 2009; Özkan \& Sarol, 2008; Özkan \& Kin-İşler, 2010). Many research studies have been conducted to determine such relationships between them and/or the effects of factors separately on the athletic performance (Alemdaroğlu, 2012; Arslan \& Aras, 2016; Caia et al., 2016; Hazır Aytar, Salman, Devrilmez, \& Şatıroğlu, 2018; Kale et al., 2009; Özkan \& Sarol, 2008; Özkan \& Kin-İsler, 2010). There have been many research studies in order to determine the best performance for even a slight improvement of the above-mentioned factors. This is because the slightest increase in performance was believed to be a reliable deciding factor between a win/loss and/or to decide the position to whom and where the athletes play in a strategic competition (Aouadi et al., 2011; Kale et al., 2009). Determinants of primary energy system usage was also another factor for performance indicators. Stored phosphagens, ATP and phosphocreatine (PCr), and breakdown of carbohydrate by alactic and lactic anaerobic pathways were to form and breakdown ATP for usable energy at high rates for highly-intensive performances (Beneke, Pollmann, Bleif, Leithauser \& Hütler, 2002; Gustin, 2001). Owen et al. (2018) stated that force production by lean body mass and body fat mass as weight \& depots of adipose tissue need to be moved against gravity (Hazır Aytar et al., 2018; Kale et al., 2009; Özkan \& Kin-İşler, 2010). Studies showed that body composition, anaerobic power and strength of athletes varies according to their respective sports branch(es) (Alemdaroğlu, 2012; Arslan \& Aras, 2016; Gökhan, Aktaş \& Aysan, 2015; Harbili, 2015; Kale et al., 2009; Özkan \& Sarol, 2008; Özkan \& Kinİşler, 2010; Potteiger, Smith, Maier, \& Foster, 2010; Wisløff, Castagna, Helgerud, Jones, \& Hoff, 2004).

Sprint is one of the determinant performance parameters for many branches of sports. Sprint capability and its components are important in determining performance in team sports and also one of

The role and contributions of each authors as in the section of IJSETS Writing Rules "Criteria for Authorship" is reported that: 1. Author: Contributions to the conception or design of the paper, data collection, statistical analysis, writing of the paper and final approval of the version to be published paper; 2. Author: Data collection, statistical analysis, preparation of the paper according to rules of the journal, final approval of the version to be published paper. 3. Author: Data collection, statistical analysis, preparation of the paper according to rules of the journal, final approval of the version to be published paper. 4. Author: Data collection, statistical analysis, final approval of the version to be published paper.

${ }_{1}^{1}$ Correspondin Author: Sports Management Department, Yozgat Bozok University, Yozgat/Turkey, nigar.kucukkubas@hotmail.com $10000-0003-0886-8923$ ${ }^{2}$ Coaching Department, Haliç University, Istanbul/Turkey. (DD 0000-0002-1439-1028

${ }^{3}$ Coaching Department, Hatay Mustafa Kemal University, Hatay/Turkey. (iD) 0000-0003-2177-1624 
the main components in evaluating the achievement of athletes. Studies in relation to sprinting showed that significant (negative) correlations were found between vertical jump, long jump and body fat percentage. It was observed that isokinetic tests and/or WAnT's power production capacity could be determined in athletes (Alemdaroğlu, 2012; Harbili, 2015; Kale et al., 2009; Özkan \& Kin-İssler, 2010; Potteiger et al., 2010; Sands et al., 2004). One of the other factors that affects anaerobic power or related performance parameters is one's strength. There were many studies related to sprint, strength, power output or jumping results (Bissas \& Havenetidis, 2008; Harbili, 2015; Kale et al., 2009; Ache-Dias, Pupo, Gheller, Külkamp, \& Moro, 2016; Kons, Ache-Dias, Detanico, Barth, \& Dal Pupo, 2018; Özkan \& Kin-İşler, 2010). Sprint performance was produced by stride length and stride frequency which were results of physiologic and neuromuscular mechanisms (Bissas, \& Havenetidis, 2008; Alemdaroğlu, 2012; Aslan, Büyükdere, Köklü, Özkan \& Şahin Özdemir, 2011; Wisløff et al., 2004). Many critical studies demonstrated that sprint performance depended largely on the strength of the leg muscles, relative to stride length (Weyand, Sternlight \& Bellizzi, 2000; Kale et al., 2009).

In light of the above-mentioned studies, the aim of the study was to determine the relationship between body composition compartments, jumping, sprinting, static strength, and anaerobic power of athletes.

\section{METHOD}

\section{Procedures}

The study was conducted in the Hatay Mustafa Kemal University, School of Physical Education and Sports, Exercise Physiology Laboratory with an accredited exercise physiologist. Testing procedures were explained to the subjects. After all of the anthropometric measurements were conducted, subjects were directed to perform 10 minutes of warm-up exercises for vertical jump test in the laboratory and were then taken to the hall to test 30-meter sprint. After 30 minutes rest interval, subjects completed WAnT on the same day in the laboratory. Measurements were completed in the morning between 09:0012:00am. The investigation was conducted in accordance to the Declaration of Helsinki.

\section{Participants}

19-27 years old athletes, training 2 hours/day, 4 days/week, for at least 4 years participated voluntarily in the study. 28 male $(23.11 \pm 1.71$ years; 1 fitness, 1 mountain climber, 1 swimmer, 15 football, 2 basketball, and 8 tennis players), and 19 female ( 3 zumba, 1 cross country runner, 5 basketball, 2 football, 6 tennis, 2 volleyball players) athletes were tested in the study.

Anthropometric Measurements: Body weight (BW) was measured with t-shirt and shorts on and without shoes by using $\pm 0,01 \mathrm{~kg}$ sensitive Bioelectrical Impedance Analyser (Tanita TBF $418 \mathrm{M}$ TANITA, Japan). Height was measured by with deep inspiration on Frankfort plane (SECA®, France). Skinfold sites which were triceps, biceps, abdomen, subscapula, thigh, calf, chest were measured according to Nieman, (1999) by using Skinfold Caliper (Holtain Ltd., Crymych, UK).

Bioelectrical Impedance Analysis (BIA) Measurements: Body Fat Percentage (\%BF) and Lean Body Mass (LBM) parameters were recorded from the output of manufacturers' data. Tanita TBF $418 \mathrm{M}$ (TANITA, Japan), model is a tetra-polar hand to foot model (frequency $50 \mathrm{kHz}$; current was/is $550 \mu \mathrm{A}$ ). "Athlete mode" was used to measure \%BF and LBM for the subjects.

Wingate Anaerobic Power Test (WAnT): Monark 894E bicycle ergometer (Monark-Crescent Sweden), computer, appropriate software and weights were used to determine anaerobic power. The test protocol was explained in detail to the athletes. All subjects were directed to get used to the bicycle ergometer, adjust the seating height and handlebar before the test. A warm-up was then directed to be 5 minutes at pedal speed, approximately $70-80 \mathrm{rpm} / \mathrm{min}$ without any resistance. After a $3 \mathrm{~min}$ rest, the feet of the volunteers were fastened to the pedals. The force was adjusted to $75 \mathrm{gr} / \mathrm{kg}$ of BW. Subjects began 5 seconds of weightless pedaling for acceleration, immediately succeeded by resisted pedaling for 30 seconds at maximal speed, against a constant force. They were motivated throughout the test. After 30 seconds, they were performed pedaling 5 minutes without any resistance for recovery purposes. $\mathrm{WAnT}_{\mathrm{PP}}$ and $\mathrm{WAnT}_{\mathrm{MP}}$ of the volunteers were determined as absolute (Watt) and relative (Watt.kg-1) values by computer software (Bar-Or, 1987).

Vertical Jump: Vertical jump was measured as described in Bosco and Komi (1979). Triggered timer by the feet of the subject release and touch town period was recorded (BOSCO Ergojump, Finland). To standardize the measurements, the subjects were directed to bend their knees to about $90^{\circ}$ and hold their 
hands on their hips during the jump. Subjects tried the test two times; best performance was used as to evaluate their results.

30 m Sprint Test: After ten minutes warm-up and stretching exercises, subjects were informed to wait at a self-starting time behind the $0.5 \mathrm{~m}$ first timing gate. Starting their sprint test at the first gate, they performed at their own respective maximum performances twice, along with 15 minutes rest interval. Best performance result was recorded in the study.

\section{Statistical analysis}

SPSS 23.0 (Statistical Program for Social Sciences) was used to do descriptive statistics and Pearson Product Moment Correlations. The normality of data was verified using the Shapiro-Wilk Multivariate Test and using skewness and kurtosis coefficients.

\section{RESULTS}

Descriptive results for the athletes' characteristics were reported that age for male $(\mathrm{n}=28)$ and female athletes $(\mathrm{n}=19)$ were $23.11 \pm 1.71$ and $21.95 \pm 2.37$ years old respectively (Range $=19-27$ years for both sex). BW of whom were $72.0 \pm 10.76 \mathrm{~kg}$ (Range $=52-93 \mathrm{~kg})$ and $55.74 \pm 5.89 \mathrm{~kg}$ (Range $=48-$ $66 \mathrm{~kg})$ and height of whom were $175.89 \pm 5.93 \mathrm{~cm}($ Range $=165-186)$ and $165.4 \pm 5.07 \mathrm{~cm}($ Range $=$ 155 - 180) respectively.

Table 1. Physical Characteristics of Male and Female Athletes

\begin{tabular}{lcccccc}
\hline \multicolumn{1}{c}{ Parameters } & Male $(\mathbf{n}=\mathbf{2 8})$ & Female $(\mathbf{n}=\mathbf{1 9})$ & \multicolumn{2}{c}{ Female } & \multicolumn{2}{c}{ Male } \\
\hline Age (year) & $\overline{\mathbf{x}} \pm$ sd & $\overline{\mathbf{x}} \pm \mathbf{s d}$ & Min. & Max. & Min. & Max. \\
Body Weight $(\mathrm{kg})$ & $23.11 \pm 1.71$ & $\mathbf{2 1 . 9 5} \pm \mathbf{2 . 3 7}$ & $\mathbf{3 0}$ & $\mathbf{6 0}$ & 36 & 69 \\
Height $(\mathrm{cm})$ & $72.00 \pm 10.76$ & $\mathbf{5 5 . 7 4} \pm \mathbf{5 . 8 9}$ & $\mathbf{4 8}$ & $\mathbf{6 6}$ & 52 & 93 \\
BF\% & $175.9 \pm 5.93$ & $\mathbf{1 6 5 . 0 0} \pm \mathbf{5 . 0 7}$ & $\mathbf{1 5 5}$ & $\mathbf{1 8 0}$ & 165 & 186 \\
LBM\% & $11.65 \pm 5.94$ & $\mathbf{1 8 . 9 6} \pm \mathbf{6 . 8 8}$ & $\mathbf{6 , 8}$ & $\mathbf{2 7 , 7}$ & 3,5 & 26,7 \\
LBM $(\mathrm{kg})$ & $88.34 \pm 5.94$ & $\mathbf{8 1 . 0 3} \pm \mathbf{6 . 8 8}$ & $\mathbf{7 2 . 3}$ & $\mathbf{9 3 . 2 0}$ & 73,3 & 96,5 \\
\hline
\end{tabular}

LBM: Lean body mass, BF: Body fat, maks: maksimum; min: minimum; sd: standard deviation

57SKF; vertical jump, $30 \mathrm{~m}$ sprint, static strength and WAnT (peak and mean) descriptive results of athletes were presented in Table 2 .

Table 2. Descriptive results of Skinfold Thicknesses, Vertical Jump, $30 \mathrm{~m}$ Sprint, Wingate Anaerobic Power Test and Strength of Male and Female Athletes

\begin{tabular}{|c|c|c|c|c|c|c|}
\hline \multirow[b]{2}{*}{ Parameters } & \multirow{2}{*}{$\begin{array}{l}\text { Male } \\
\overline{\mathbf{x}} \pm \text { sd }\end{array}$} & \multirow{2}{*}{$\begin{array}{c}\text { Female } \\
\overline{\mathbf{X}} \pm \text { sd }\end{array}$} & \multicolumn{2}{|c|}{ Female $(n=19)$} & \multicolumn{2}{|c|}{ Male $(n=28)$} \\
\hline & & & Min. & Max. & Min. & Max. \\
\hline Triceps & $10.6 \pm 3.8$ & $15.3 \pm 5.3$ & 8 & 26 & 5 & 18 \\
\hline Biceps & $4.6 \pm 1.7$ & $7.1 \pm 1.8$ & 5 & 13 & 3 & 10 \\
\hline Subscapula & $12.2 \pm 4.3$ & $9.7 \pm 2.3$ & 7.1 & 15.4 & 8 & 28.5 \\
\hline Thigh & $14.4 \pm 6.5$ & $19.8 \pm 6.3$ & 13 & 35 & 6 & 32 \\
\hline Calf & $8.6 \pm 3.7$ & $17 \pm 3.3$ & 10 & 23 & 4 & 19 \\
\hline Chest & $7.7 \pm 4.4$ & $11 \pm 2.4$ & 6 & 15 & 4 & 22 \\
\hline Abdominal & $15.3 \pm 4.8$ & $13.3 \pm 2.9$ & 9.3 & 18.6 & 8 & 28 \\
\hline$\Sigma 7 \mathrm{SKF}(\mathrm{mm})$ & $73.7 \pm 25.4$ & $93.4 \pm 17.3$ & 74.3 & 128.5 & 44.4 & 144.9 \\
\hline Vertical Jump (cm) & $59.3 \pm 6.07$ & $50.32 \pm 6.21$ & 30 & 60 & 36 & 69 \\
\hline 30 m Sprint (sec) & $4.40 \pm 0.23$ & $5.21 \pm 0.48$ & 4.52 & 6.34 & 4.01 & 4.93 \\
\hline $\mathrm{WAnT}_{\mathrm{PP}}(\mathrm{W})$ & $855.8 \pm 149.16$ & $541.95 \pm 81.77$ & 402 & 673 & 608 & 1134 \\
\hline WAnTMP (W) & $606.7 \pm 98.66$ & $374.0 \pm 47.16$ & 310 & 483 & 415 & 810 \\
\hline FI $(\%)$ & $56.5 \pm 8.52$ & $59.4 \pm 10.79$ & 32.1 & 82.1 & 39.3 & 72.3 \\
\hline Back Strength (kgf) & $128.32 \pm 23.89$ & $72.37 \pm 12.98$ & 42 & 97 & 73 & 175 \\
\hline Leg Strength (kgf) & $124.86 \pm 28.99$ & $78.11 \pm 18.65$ & 50 & 113 & 75 & 199 \\
\hline
\end{tabular}

इ7SKF: sum of triceps, biceps, subscapula, thigh, calf, chest, abdominal; LBM\%: Lean Body Mass Percentage; LBM: Lean Body Mass; BF\%: Body Fat Percentage WAnTPP: WAnT peak power, WAnTMP: WAnT mean power, FI: Fatigue Index. 
In this study, the relationships between $\Sigma 7 \mathrm{SKF}$, vertical jump, $30 \mathrm{~m}$ sprint, back $\&$ leg strength and anaerobic power obtained from WAnT test were determined for athletes training in different sports (Table 3).

For male athletes, significant moderate negative correlation results were obtained between \%LBM and static strength of leg muscles $(\mathrm{p}<0.05)$ and $\mathrm{WAnT}_{\mathrm{MP}}(\mathrm{p}<0.05)$. In addition, there were significant high negative correlations between LBM\% and $\Sigma 7 \mathrm{SKF}(\mathrm{p}<0.01)$. There were also significant correlations between BF $\%$ and, $\Sigma 7 \mathrm{SKF}(\mathrm{p}<0.01)$, leg strength $(\mathrm{p}<0.05), \mathrm{WAnT}_{\mathrm{MP}}(\mathrm{W})(\mathrm{p}<0.05)$ respectively. Moreover, it was found significant correlations between $\Sigma 7 \mathrm{SKF}(\mathrm{mm})$ and LBM $(\mathrm{kg})$ $(\mathrm{p}<0.01), \mathrm{BF} \% \mathrm{p}<0.01$, back strength $(\mathrm{kgf})(\mathrm{p}<0.05)$, leg strength $(\mathrm{kgf})(\mathrm{p}<0.01), \mathrm{WAnT}_{\mathrm{PP}}(\mathrm{W})$ $(\mathrm{p}<0.01)$, and $\mathrm{WAnT}_{\mathrm{MP}}(\mathrm{W})(\mathrm{p}<0.01)$. The only LBM-related significant moderate correlation result for female athletes was between LBM $(\mathrm{kg})$ and Leg Strength $(\mathrm{p}<0.01)$.

Table 3. Pearson Product Moment Correlation Between Body Composition Compartments and $\Sigma 7$ SKF, Vertical Jump, $30 \mathrm{~m}$ Sprint, Static Strength and Wingate Anaerobic Power Test Results for Male (n=28) And Female $(\mathrm{n}=19)$ Athletes.

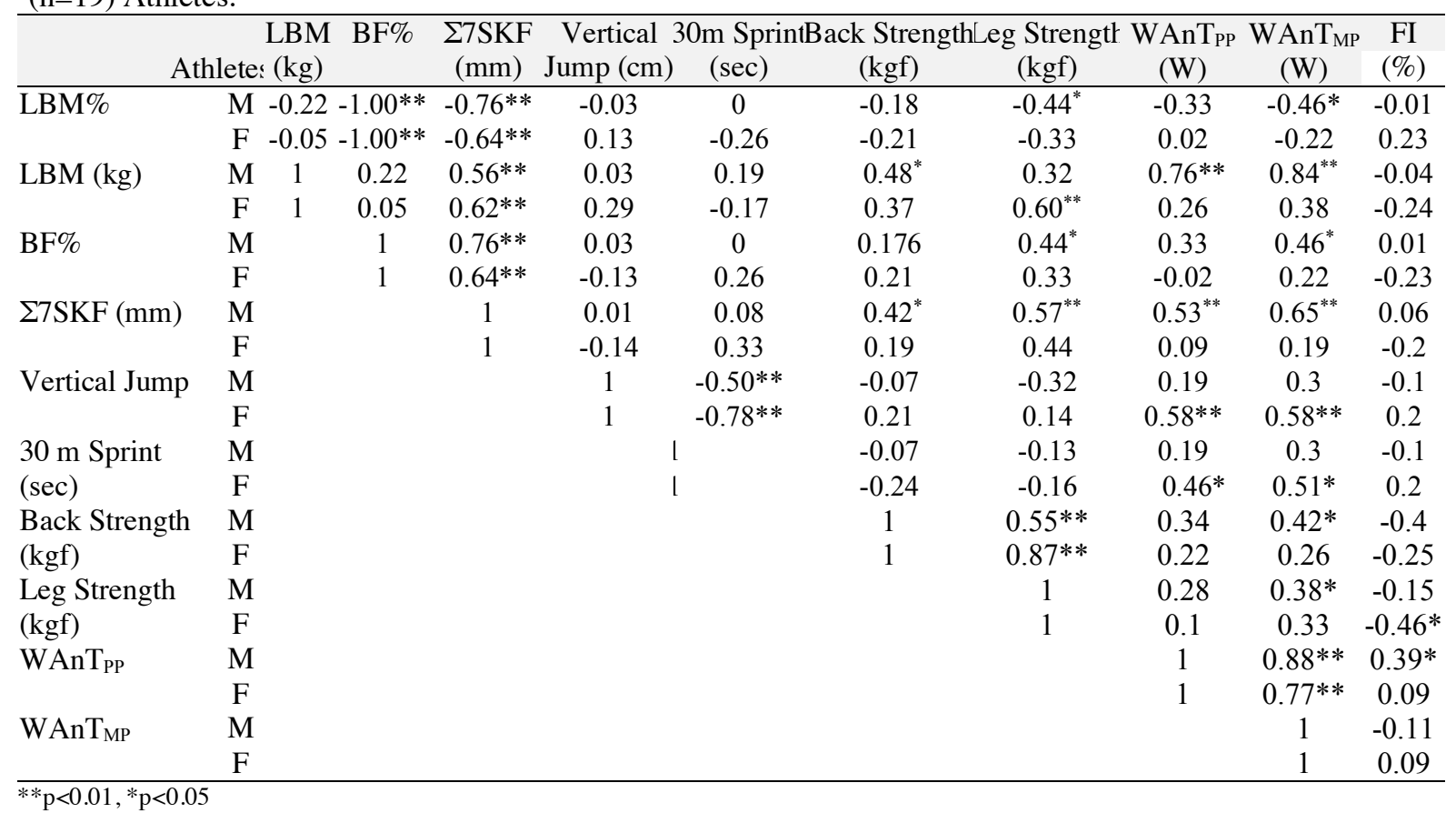

There was no significant relationship between fat compartments of body composition (BF\% and $\Sigma 7 \mathrm{SKF}$ ) and vertical jump or $30 \mathrm{~m}$ sprint performances for female and male athletes. In addition to that, there was no found relationship between fat compartments ( $\mathrm{TSKF}$ and BF\%) and/or any of the performance parameters of vertical jump, $30 \mathrm{~m}$ sprint, $\mathrm{WAnT}_{\mathrm{PP}}$, $\mathrm{WAnT}_{\mathrm{MP}}$ and $\mathrm{FI}$ for female athletes.

Furthermore, there were significant negative correlations for female athletes between LBM\% and $\mathrm{BF} \%, \Sigma 7 \mathrm{SKF}(\mathrm{mm})$. Significant and/or moderate positive correlations were found $(\mathrm{p}<0.01)$ between LBM $(\mathrm{kg})$ and $\Sigma 7 \mathrm{SKF}(\mathrm{mm})$ for males and female athletes.

There were significant positive correlation coefficient results between $\mathrm{LBM}(\mathrm{kg})$ and back strength (kgf) $(\mathrm{p}<0.05), \mathrm{WAnT}_{\mathrm{PP}}(\mathrm{W})(\mathrm{p}<0.01), \mathrm{WAnT}_{\mathrm{MP}}(\mathrm{W})(\mathrm{p}<0.01)$, and $57 \mathrm{SKF}(\mathrm{mm})(\mathrm{p}<0.01)$ for male athletes.

\section{DISCUSSION}

Why the analysis of body composition compartment, vertical jump, $30 \mathrm{~m}$ sprint, static strength, anaerobic power were the factors which were directly and/or indirectly related to each other and/or precise results couldn't be reported for athletes' performances (Aouadi et al., 2011; Granier et al., 1995; Caia et al., 2016; Harbili, 2015; Hazır Aytar et al., 2018; Owen et al., 2018; Özkan \& Kin-İşler, 2010; Sands et al., 2004). The body composition parameters were important indicators that affects performance due to the force production by muscle against gravity by fat mass and BW. The muscle mass as a producer of power, strength or fat mass as adipose depots and hormonal tissue affects aerobic 
\& anaerobic energy production (Owen et al., 2018; Özkan \& Kin-İşler, 2010). Different approaches for the methods such as age \& sex groups, training level or sport-specific demands made the analysis difficult to state and evaluate the relationship.

Descriptive results of the study demonstrate these figures based on the average age of male participants (studied): $23.11 \pm 1.71$ years, body weight $72.0 \pm 10.76 \mathrm{~kg}$, height $175.89 \pm 5.93 \mathrm{~cm}$. Caia et al. (2016) studied along with the same age group $(22.6 \pm 4.1$ years), BW $(79.7 \pm 14.5 \mathrm{~kg})$ and height $(177.4 \pm 8.6 \mathrm{~cm})$. In addition to this, Bissas and Havanetidis (2008) conducted a study with similarlytrained elite male soccer players $25.5 \pm 3.0$ years; $78.1 \pm 8.4 \mathrm{~kg}$ and $179 \pm 0.5 \mathrm{~cm}$ and with the similar age group of $25.8 \pm 2.9$ years old and similar physical characteristics. Another study conducted by Hazir Aytar et al. (2018) determined that the relationship(s) between performance and anaerobic parameters for elite badminton players were also similar in terms of final results of physical characteristics within the age group of $20.2 \pm 2.2$ years and height of $177.3 \pm 5.8 \mathrm{~cm}$ and body weight of $74.5 \pm 6.2 \mathrm{~kg}$. Continuing, a study conducted by Wisløff et al. (2004) demonstrated that the height and weight of subjects (studied) were $177.3 \pm 4.1 \mathrm{~cm}$ and $76.5 \pm 7.6 \mathrm{~kg}$ respectively, which proved to be high in similarity with the results of the present study. The subjects' height $(194.8 \pm 5.7 \mathrm{~cm})$ and weight $(92.3$ $\pm 9.8 \mathrm{~kg}$ ) of Alemdaroğlu (2012) study also included close physical characteristics for similar ages (25.1 \pm 1.7 years) in male basketball players (not parallel with the results of the present study). The reason for the difference might be to whom the characteristics of the subjects of the study were mixed with group of athletes in contrast to first division basketball players of the study). BF\% of basketball players of Alemdaroğlu (2012) study was $10.1 \pm 5.1$ similar to the present study $(11.65 \pm 5.94)$. Althougth the study of Dilber and Doğru (2018) showed that sedantary males 12 weeks post-training strength results (leg and back static strength) were similar, respective body weight of the subjects $(79.01 \pm 10.85)$ and $\mathrm{BF} \%(18.95 \pm 4.63)$ were not parallel with the present study. The 12 weeks of strength training might be effective for the static strength results, though BF\% difference could possibly take some time to change.

Similarly, Hazır Aytar et al. (2018) studied with elite badminton female players - results: (age = $19.5 \pm 2.5$ years, height $=166.7 \pm 8.2 \mathrm{~cm}, \mathrm{BW}=58.2 \pm 8.1 \mathrm{~kg}$ ) and the Caia et al., (2016) with female athletes' (height $=163.9 \pm 7.0 \mathrm{~cm}$ and $\mathrm{BW}=59.9 \pm 7.1 \mathrm{~kg}$ ) which were parallel with the study - present results of female athletes: $(21.95 \pm 2.37$ years, body weight $55.74 \pm 5.89 \mathrm{~kg}$, height $165 \pm 5.07 \mathrm{~cm})$.

$\Sigma 7 \mathrm{SKF}$; vertical jump, 30m sprint, static strength and WAnT (peak and mean) descriptive results of athletes were presented in Table 2. Although the results for male athletes demonstrated an impressive vertical jump test results $(59.3 \pm 6.07 \mathrm{~cm})$ similar with the Wisløff et al. (2004) study of elite soccer players results $(56.4 \pm 4.0 \mathrm{~cm})$, Lockie et al. (2018) the study of soccer players $(51 \pm 6.0 \mathrm{~cm})$, and Aslan et al. (2011) study of athletes' results $(61.77 \pm 7.3 \mathrm{~cm})$ in contrast to the basketball players' $(32.91 \pm$ $3.82 \mathrm{~cm}$ ) of Alemdaroğlu (2012) study, ex-national/regional sprinter male trained subjects $(34.4 \pm 5.5$ $\mathrm{cm}$ ) of Bissas and Havenetidis (2008) study and male badminton players $(34.1 \pm 3.4 \mathrm{~cm})$ of Hazır Aytar et al. (2018). $30 \mathrm{~m}$ sprint $(4.40 \pm 0.23 \mathrm{sec})$ results were similar to the basketball players $(4.34 \pm 0.15 \mathrm{sec})$ of Alemdaroğlu (2012) study, whereas Wisløff et al. (2004) elite male soccer players $(4.0 \pm 0.2 \mathrm{sec})$ were faster than those from the basketball players of the Alemdaroğlu (2012) study and the present study.

The study conducted by Hazır Aytar et al. (2018) vertical jump results $(26.8 \pm 3.2 \mathrm{~cm})$ for female were not only less than half of the present study, but also very different in terms of the results $(50.32 \pm$ $6.21 \mathrm{~cm}$ ). Furthermore, Division 1 female soccer players study of Lockie et al. (2018) $30 \mathrm{~m}$ sprint result $(4.719 \pm 0.202 \mathrm{sec})$ was better than that of the present study of female athletes' result $(5.21 \pm 0.48 \mathrm{sec})$. Skinfold thicknesses and body composition parameter results of Arslan and Aras (2016) also showed higher skinfold parameters (Table 2) and BF\% (17.7 \pm 3.2 for triathletes and $19.3 \pm 3.2$ for cyclist) results with the results of the present study (Table 1).

The results of the present study confirm that high significant correlations exist between LBM and WAnT parameters for male athletes. Özkan and Kin-İşer (2010) found that leg volume \& leg mass were related with isokinetic strength results for volleyball, football and basketball players. This of which could be interpreted to be muscle mass and its contents should be considered in evaluating the performance results. In terms of WAnT results from males, WAnT $855.8 \pm 149.16 \mathrm{~W}$, $\mathrm{WAnT}_{\mathrm{MP}} 606.7 \pm 98.66 \mathrm{~W}$ and FI \%56.5 \pm 8.52 were final results for male athletes in the present study. The study of Alemdaroğlu (2012) (WAnT ${ }_{\mathrm{PP}} 955.31 \pm 117.86 \mathrm{~W}, \mathrm{WAnT}_{\mathrm{MP}} 702.81 \pm 79.26 \mathrm{~W}$ 
and FI \%54.67 \pm 7.34$)$ and Harbili $(2015)\left(\mathrm{WAnT}_{\mathrm{PP}} 951.6 \pm 86.9 \mathrm{~W}, \mathrm{WAnT}_{\mathrm{MP}} 683.7 \pm 40.5 \mathrm{~W}\right.$ and FI $\% 59.9 \pm 6.3)$ were results from basketball players. Arslan and Aras (2016) study for cyclists' $\left(\mathrm{WAnT}_{\mathrm{PP}} 933.3 \pm 189.5 \mathrm{~W}, \mathrm{WAnT}_{\mathrm{MP}} 702.5 \pm 139.3 \mathrm{~W}\right.$ and FI \%49.3 \pm 2.2$)$, Sands et al. (2004) exnational/regional sprinter university athletes' (WAnT $984.82 \pm 133.05 \mathrm{~W}$ and WAnT $\mathrm{MP}_{\mathrm{MP}} 690.27 \pm$ $77.28 \mathrm{~W}$ ) and Potteiger et al. (2010) study with $20.7 \pm 1.6$ years old in division 1 men's hockey athletes' $\left(\mathrm{WAnT}_{\mathrm{PP}} 1.305 \pm 177.2 \mathrm{~W}\right.$ and $\mathrm{WAnT}_{\mathrm{MP}} 842.8 \pm 92.4 \mathrm{~W}$ ) demonstrated that WAnT results of these studies were higher than that of the present study. Likewise, the Granier et al. (1995) study with sprinter and middle-distance competitive runners showed that sprinter had higher results of $\mathrm{WAnT}_{\mathrm{PP}}$ $924 \pm 105 \mathrm{~W}, \mathrm{WAnT}_{\mathrm{MP}} 662 \pm 61 \mathrm{~W}$ and FI $\% 60 \pm 6$ but results were overall similar for middledistance competitive runners of WAnT $\mathrm{PP}_{\mathrm{P}}(842 \pm 123 \mathrm{~W})$ and $\mathrm{WAnT}_{\mathrm{MP}}(578 \pm 64 \mathrm{~W})$ and $\mathrm{FI}(\% 52 \pm$ 4). The triathletes of Arslan and Aras (2016) (WAnT $796.4 \pm 74.6 \mathrm{~W}, \mathrm{WAnT}_{\mathrm{MP}} 586.9 \pm 45.8 \mathrm{~W}$ and FI \%52.4 \pm 4.1 ) and regional amateur Turkish National League soccer players of Harbili (2015) study $\left(\mathrm{WAnT}_{\mathrm{PP}} 809.7 \pm 90.6 \mathrm{~W}, \mathrm{WAnT}_{\mathrm{MP}} 618.0 \pm 50.1 \mathrm{~W}\right.$ and $\left.\mathrm{FI} \% 51.5 \pm 5.8\right)$ results were also parallel with the results of the present study. The reason of very high results of WAnT would be the level of the first division basketball players of the Alemdaroğlu (2012) Turkish National League Division III basketball players of Harbili (2015), Granier et al. (1995) competitive sprinters, Arslan \& Aras (2016) cyclists, Sands et al. (2004) ex-national/regional sprinter university athletes' and Potteiger et al. (2010) with $20.7 \pm 1.6$ years old, division 1 men's hockey athletes' could be their higher training level and/or requirements demanded of their respective sports themselves. The abovementioned studies should be considered and carefully evaluated by coaches \& sports scientists while measuring \& evaluating the performance parameters, training follow-up and talent identification.

The relationship of the anaerobic test results were a controversial issue due to test protocols, applied \& non-standard tests (especially in sprinting), sport skill needs, body composition compartments' effects and size. To determine the relationship between athletic performance and anaerobic results, the parameters of anaerobic tests were analyzed in the present study. One of the important parameters of body composition compartment was BF\%. A significant correlation was not found between $30 \mathrm{~m}$ sprint performance and $\mathrm{BF} \%$. Although there was a significant negative correlation between squat jump and BF\% (-0.494 p<0.05) in the Alemdaroğlu study (2012), no significant relationship was found between $\mathrm{BF} \%$ and $30 \mathrm{~m}$ sprint performance results. Aforementioned findings of Alemdaroğlu (2012) study were parallel with the findings of the present study for male athletes. However, between WAnT and vertical jump results were not significant (near zero correlations) and not parallel with the findings (WAnT $\mathrm{PP}_{\mathrm{PP}}$ 0.19 and $\mathrm{WAnT}_{\mathrm{MP}} 0.3 \mathrm{p}>0.05$ ) of the present study. Similarly, Saç and Taşmektepligil (2011) study results of the athletes also demonstrated an insignificant correlation between the coefficients found between WAnT and vertical jump $(\mathrm{r}=0.36 \mathrm{p}>0.01)$ - not similar with the results of the present study $(\mathrm{r}$ $=0.58 \mathrm{p}<0.01)$. The correlation between the coefficient results obtained in the study of Saç and Taşmektepligil (2011), $30 \mathrm{~m}$ sprint and FI $(\mathrm{r}=0.562 \mathrm{p}<0.001)$, FI and vertical jump $(\mathrm{r}=0.054 \mathrm{p}=$ $0.775)$, FI and sprint $(r=0.132 \mathrm{p}=0.486)$, and vertical jump and sprint $(\mathrm{r}=0.083 \mathrm{p}=0.665)$ were supportive of our claim. The abovementioned study showed that if the athletes have different sports and level of training, all the parameters and analysis could change the interpretation for each factor.

There were significant correlations between BF\% and, $27 \mathrm{SKF}(\mathrm{mm}) 0.76 \mathrm{p}<0.01)$ and between $\Sigma 7 \mathrm{SKF}(\mathrm{mm})$ and LBM $(\mathrm{kg}) 0.56 \mathrm{p}<0.01, \mathrm{BF} \% 0.76 \mathrm{p}<0.01$, back strength (kgf) $0.42 \mathrm{p}<0.05$, leg strength (kgf) $0.57 \mathrm{p}<0.01, \mathrm{WAnT}_{\mathrm{PP}}(\mathrm{W}) 0.53 \mathrm{p}<0.01$, $\mathrm{WAnT}_{\mathrm{MP}}(\mathrm{W}) 0.65 \mathrm{p}<0.01$ for male athletes. The body composition parameters and correlation results demonstrated that the mixed group of athletes should be evaluated as a whole, in regards to either their BF\% $(11.65 \pm 5.94)$ or LBM $(62.65 \pm 8.15)$. Mayhew, Hancock, Rollison, Ball and Bowen (2001) found the correlation between coefficients in their study which revealed the relationship between the factors affecting the anaerobic power, the body composition compartments and leg extension strength. The study demonstrated that anaerobic power and leg extension strength was $0.66(\mathrm{p}<0.01)$ and the correlation between FFM and anaerobic power was very high $0.80(\mathrm{p}<0.01)$ for males. In spite of this, the results remained that all body composition parameters (except $\mathrm{BF} \%$ ) and $\mathrm{WAnT}_{\mathrm{MP}}$ showed moderate to high significant correlations (ranges between $0.46-0.84$ ) for males. Kons et al. (2018) found that body size with adjusted peak power output $(\mathrm{r}=0.73)$ was related to the vertical jump, though these findings were not parallel with the present study. The trend showed that anaerobic power \& capacity might be related with the body compartments for 
males. This is in contrast to females, who had no significant correlation coefficients between body composition and WAnT results.

The only significant negative correlation result was between \% LBM and static strength of leg muscles $(r=-0.44 \mathrm{p}<0.05)$ for male athletes. There were similar results of correlation between \% LBM and $\mathrm{WAnT}_{\mathrm{MP}}(\mathrm{r}=-0.46 \mathrm{p}<0.05)$ for male athletes. These results showed the lower-than-expected figures between static strength and WAnT results were due to muscle mass, as a producer of force \& strength tissue. Important to add is that the Alemdaroğlu (2012) study also found moderate and/or not significant correlation between isokinetic strength parameters and $\mathrm{WAnT}_{\mathrm{PP}} \& \mathrm{WAnT}_{\mathrm{MP}}$ results. There were significant negative correlations for male athletes between LBM\% and BF \% $(r=-1.00 \mathrm{p}<0.01)$, 57SKF $(\mathrm{r}=-0.76 \mathrm{p}<0.01)$. The reason behind these controversial findings could be that LBM was calculated as a remainder of the two-compartment model, representing all non-fat mass including bone, muscle mass, etc.

There was no significant relationship between fat compartments of body composition (BF\% and $\Sigma 7 \mathrm{SKF}$ ), vertical jump or $30 \mathrm{~m}$ sprint performances for female and male athletes. Although, Bissas and Haveniditis (2008) found that maximal running velocity and vertical jump had no significant correlation between the two anaerobic tests ( $\mathrm{WAnT}_{\mathrm{PP}}$ and $\mathrm{WAnT}_{\mathrm{MP}}$ ) for male athletes. The results of the studies of Alemdaroğlu (2012) and Saç and Taşmektepligil (2011) (between $\mathrm{WAnT}_{\mathrm{PP}}$ and $45.73 \mathrm{~m}$ sprint $\mathrm{r}=-0.177 \mathrm{p}=0.351$ ) found no significant correlation between WAnT tests and field tests (drill tests or $30 \mathrm{~m}$ sprint) and were parallel with the present study. Furthermore, in the present study, there was no significant correlation between static strength parameters and $30 \mathrm{~m}$ sprint test. The results were not parallel with the results of Wisløff et al. (2004) elite male soccer players correlation results of 0.71 $\mathrm{p}<0.01$ and significant correlation between one repetition maximum $0.71(\mathrm{p}<0.01)$ results and vertical jump correlation of $0.78(\mathrm{p}<0.02)$. Aslan et al. (2012) findings of 80 male Physical Education and Sports College students with a mean age of $22.17 \pm 1.97$ years and a body weight average of $73.27 \pm 7.96 \mathrm{~kg}$ also parallel with the present study found that there was a significant correlation between anaerobic power and height, body weight, vertical jump and $20 \mathrm{~m}$ sprint. A high level of significant correlation for female athletes and a moderate significant correlation for male athletes between vertical jump and sprint parameters were expected as they are both are (theoretically) derivatives of strength. Loturco et al. (2015) study with the top-level sprinters supported the findings of the theoretical point of view that correlation between vertical jump and $100 \mathrm{~m}$ sprint result in the competitive season were very high $(\mathrm{r}=$ -0.82 ). The study was led on that using vertical jump test is useful, safe and easy to predict performance improvement. Furthermore, increasing the number of sprinters with different levels could explain the percentage of the improvement by vertical jump. Berthoin, Dupont, Mary and Gerbeaux (2001) also found a significant correlation between sprinting (mean acceleration during $2 \mathrm{sec}$ ) and vertical jump as $0.62(\mathrm{p}<0.01)$, could be evaluated using relating energetics and kinematics of the sprinting start. In the present study, the significant moderate correlation coefficients between vertical jump and 30 sprint results of -0.50 for male and -0.78 female athletes could explain performance in a similar way for male and female athletes.

In addition to that, there was no relationship between fat compartments ( $7 \mathrm{SKF}$ and BF \%) and any of the performance parameters of vertical jump, sprinting, $\mathrm{WAnT}_{\mathrm{PP}}, \mathrm{WAnT}_{\mathrm{MP}}$ and $\mathrm{FI}$ for female athletes. These results were expected due to the fat mass not as a producer of force and reducing effects on weight-related performance parameters (Silva, 2018). Furthermore, there were significant negative correlations found for female athletes between LBM\% and BF\%, $27 \mathrm{SKF}$ (mm); -1.000 -0.64, respectively. Proportional effect of fat mass was just as important as LBM content and ratio, due to the force and strength requiring sports by using the muscle mass to develop (Silva, 2018). There were significant moderately positive correlations $(0.62 \mathrm{p}<0.01)$ between LBM $(\mathrm{kg})$ and $\Sigma 7 \mathrm{SKF}(\mathrm{mm})$ female athletes and $(0.56 \mathrm{p}<0.01)$ for males demonstrated that low BF\% and low $\Sigma 7 \mathrm{SKF}$ their trained body composition. The results of the present study demonstrated that LBM and anaerobic power output results supports the results that there were significant positive correlated in terms of coefficient results between LBM $(\mathrm{kg})$ and back strength $(\mathrm{kgf})(\mathrm{r}=0.48 \mathrm{p}<0.05)$, WAnT $_{\mathrm{PP}}(\mathrm{r}=0.76 \mathrm{p}<0.01)$, WAnT $_{\mathrm{MP}}(\mathrm{r}=0.84$ $\mathrm{p}<0.01), \Sigma 7 \mathrm{SKF}(\mathrm{mm})(\mathrm{r}=0.56 \mathrm{p}<0.01)$ for male athletes. The Mayhew et al. (2001) findings for females demonstrated that correlations between anaerobic power and leg extension were $0.56(\mathrm{p}<0.01)$ and correlations between FFM and anaerobic power was $0.37(\mathrm{p}<0.01)$. Moreover, FFM and leg extension correlation was $0.61(\mathrm{p}<0.01)$. With the same point of view, theoretical knowledge of body 
composition and hormonal effect demonstrated that LBM content of male was always lower than that of the females. The reason for that being only LBM-related significant results for female athletes was between LBM $(\mathrm{kg})$ and Leg Strength was $\mathrm{r}=0.60(\mathrm{p}<0.01)$.

For female athletes, results of the present study as follows; vertical jump $50.32 \pm 6.21 \mathrm{~cm}, 30 \mathrm{~m}$ sprint $5.21 \pm 0.48 \mathrm{sec}$, back strength $72.37 \pm 12.98 \mathrm{kgf}$ and leg strength $78.11 \pm 18.65 \mathrm{kgf}$. In terms of WAnT mean results of females, $\mathrm{WAnT}_{\mathrm{PP}}$ are $541.95 \pm 81.77 \mathrm{~W}, \mathrm{WAnT}_{\mathrm{MP}} 374.0 \pm 47.16 \mathrm{~W}$ (Table 2), Sands et al. (2004) found higher results (WAnT $\mathrm{PP}_{\mathrm{PP}}=746.67 \pm 220.36 \mathrm{~W}$ and $\mathrm{WAnT}_{\mathrm{MP}} 531.11 \pm 116.47$ W) for ex-national/regional sprinter university athletes than that of the present study. Zupan et al. (2009) were studied along with intercollegiate athletes $\left(\mathrm{WAnT}_{\mathrm{PP}}=598 \pm 88 \mathrm{~W}\right)$ whose results were higher, though parallel with the present study for females. The findings of the same study were not parallel with the present study of male athletes' Wingate results $\left(\mathrm{WAnT}_{\mathrm{PP}}=951 \pm 141 \mathrm{~W}\right)$. FI of the present study for $\% 59.4 \pm 10.79$ for females and \%56.5 \pm 8.52 males were higher than the Zupan study (2009) for female $(\% 42 \pm 7.9)$ and male $(\% 47 \pm 7.6)$ athletes. The correlation coefficient results also showed that no relationship between static leg strength and performance parameters of vertical jump $(r=0.14 p>0.05)$ and $30 \mathrm{~m}$ sprint tests $(r=-0.16 p>0.05)$ for females \& males $(r=-0.32$ and $-0.13 p>0.05$, respectively). The reason for static leg strength being related to unexpected correlations results could be rooted from different factors, which were the effects of muscular or neurological response in sprinting. Furthermore, static strength, vertical jump, and ballistic athletic performance of $30 \mathrm{~m}$ sprint test were similar in energetics whereas $30 \mathrm{~m}$ sprint requires the whole body of different muscular contraction of repeated pattern. It is well-stated previously in the Murphy and Wilson (1996) study that motor unit activation of static and dynamic movement were different.

In the study performed by Aslan et al., (2011) back strength was $143.16 \pm 27.44 \mathrm{kgf}$ and in this study it was measured as $128.32 \pm 23.89 \mathrm{kgf}$. The participants in the study of Aslan et al. (2012) were similar in terms of the participants, as they were the students of the Physical Education and Sports College who were training in different sports in differing branches than in the present study. Although similar groups participated in these studies, back strength performances demonstrated higher results (143.16 $\pm 27.44 \mathrm{kgf})$ than the present study. Dilber and Doğru (2018) studied with 30 sedentary males and participated in 12 weeks of training program post-test results with the similar ages of $23.62 \pm 5.39$ years of back strength (129.68 $\pm 17.14 \mathrm{kgf})$ and leg strength (125.92 $\pm 21.13 \mathrm{kgf}$ ). Results were also similar those in the present study of the athletes' back strength $(128.32 \pm 23.89 \mathrm{kgf})$ and leg strength $(124.86 \pm 28.99 \mathrm{kgf})$. In the study of Gökhan et al. (2015) leg strength was $101.83 \pm 40.48 \mathrm{kgf}$ and back strength was $75.83 \pm 19.43 \mathrm{kgf}$. In the present study, leg strength was $124.86 \pm 28.99 \mathrm{kgf}$ meanwhile back strength was $128.32 \pm 23.89 \mathrm{kgf}$. For female athletes in the present study, the only significant correlation coefficient $(r=0.60 \mathrm{p}<0.01)$ between leg strength and body composition parameters could be training level or lean body mass indicators of the muscle mass.

As a general evaluation of the results demonstrated, determining the performance parameters is a critical decision for sports scientists and coaches. Kinematic analysis of the required movement and energetics should be evaluated together with the motor unit activation. Comparing both similar volume and intensity test results were also being discussed due to the nature of the test and response of each subjects training level or sports characteristics. In the present study, it was also proven difficult to compare the sprint results due to different sprint distances, starting techniques, age differences and lack of female results. Furthermore, there were insufficient research studies for female athletes to compare, predict, help to follow-up performance and state relationship required for specific strength. In addition to all these expository inferences, Sands et al. (2004) also concluded in the WAnT test and Bosco comparison study that anaerobic capacity and power should be evaluated with the other aspects of performance such as jumping ability.

\section{CONCLUSION}

Although vertical jump, $30 \mathrm{~m}$ sprint, and WAnT seem to use anaerobic energy, ATP-PCr and anaerobic glycolysis should be evaluated separately by using other physiological responses during tests and recovery periods. The energy system usage in similar intensity and volume in the contents of the test itself have been frequently-discussed topics of indications as to predicting performance. The fact remains that the compared parameters could be evaluated by using a regression equation to use the trend for explaining the performance more effectively. 
For future studies, the number of subjects must be increased and/or evaluated by using recovery parameters of anaerobic power outputs to predict real performance results for sprinting figures. Longitudinal change in body composition, performance changes in seasonal and best performance results should be reported. Furthermore, not only should LBM be measured, but the muscle mass and recruited muscle fibers must also be measured as a force producer and both are to be evaluated together with neuromuscular response. Total power produced by muscle mass is directly related to the unit for each muscle fiber not directly related to LBM. Considering the body composition compartments and determinants of LBM (especially) should be evaluated for each branch of sport and/or grouped by playing a position with the usage of a regression analysis. Another important point for coaches or sports scientists is to not report misleading effect using the results of a similar study. Body composition compartments and regional muscle mass dependent relationships should be measured \& evaluated including this content.

\section{PRACTICAL APPLICATION}

Information from the test results should be used for coaches and sports scientists to determine athletes' training level, level(s) of improvement, and predict effectiveness of their respective training plan. Exact sport-specific strength requirements to be discussed for performance determinants have not yet been complete and versatile to use. Moreover, it is important to choose the test according to sports requirement and types of movement in respective sports.

In fact, scientific researchers have been being focused mainly on estimations of performance. At this point, a follow-up and performance-focused methods should be studied by all affecting parameters such as physiological, neurological, body composition compartment by contents, and mechanical parts, that are likely to measure, evaluate, and predict anaerobic performance of both sprint and strength outputs.

\section{REFERENCES}

Ache-Dias, J., Pupo, J. D., Gheller, R. G., Külkamp, W ., \& Moro, A. P. (2016). Output Prediction From Jump Height and Body Mass Does Not Appropriately Categorize or Rank Athletes. J Str Cond Res , 30 (3), 818-24.

Alemdaroğlu, U. (2012). The Relationship Between Muscle Strength, Anaerobic Performance, Agility, Sprint Ability and Vertical Jump Performance in Professional Basketball Players. J Hum Kinet , 31, 99-106.

Aouadi, R., Jlid, M. C., Khalifa, R., Hermassi, S., Chelly, M. S., Van Den Tillaar, R., et al. (2012). Association of anthropometric qualities with vertical jump performance in elite male volleyball players. J Sports Med Phys Fitness , 52 (1), 11-7.

Arslan, E., \& Aras, D. (2016). Comparison of body composition, heart rate variability, aerobic and anaerobic performance between competitive cyclists and triathletes. J Physical Ther Sci, 28 (4), $1325-9$.

Aslan, C. S., Büyükdere, C., Köklü, Y., Özkan, A., \& Şahin Özdemir, N. F. (2011). Elit altı sporcularda vücut kompozisyonu, anaerobik performans ve sırt kuvveti arasındaki ilişkinin belirlenmesi. Uluslararası İnsan Bilimleri Dergisi , 8 (1), 1612-28.

Bar-Or, O. (1987). The wingate anaerobic test: an update on methodology reliability and validity. Sports Med , 4, 381-94.

Beneke, R., Pollmann, C. H., Bleif, I., Leithauser, R., \& Hütler, M. (2002). How anearobic is the Wingate Anaerobic Test for humans? Eur J Appl Physiol , 87, 399-92.

Berthoin, S., Dupont, G., Mary, P., \& Gerbeaux, M. (2001). Predicting sprint kinematic parameters from anaerobic field tests in physical education students. J Str Cond Res , 15 (1), 75-80.

Bissas, A., \& Havenetidis, K. (2008). The use of various strength-power tests as predictors of sprint running performance. J Sports Med Phys Fit , 48 (1), 49-54.

Bosco, C., \& Komi, P. V. (1979). Mechanical characteristics and fiber composition of human leg extensor muscles. Eur J Appl Physiol , 41, 275-84.

Caia, J., Weiss, L. W., Chiu, L. Z., Schilling, B. K., Paquette, M. R., \& Relyea, G. E. (2016). Do lowerbody dimensions and body composition explain vertical jump ability? J Str Cond Res , 30 (11), 3073-83. 
Dilber, A. O., \& Doğru, Y. (2018). The Effect of High-Intensity Functional Exercises on Anthropometric and Physiological Characteristics in Sedantery. Int J Sport, Exerc \& Train Sci , 4 (2), 64-9.

Gökhan, İ., Aktaş, Y., \& Aysan, H. A. (2015). Amatör Futbolcuların Bacak Kuvveti ile Sürat Değerleri Arasındaki İlişkinin İncelenmesi. Int J Sci Cult Sports (4), 47-54.

Granier, P., Mercier, B., Mercier, J., Anselme , F., \& Prefaut, C. (1995). Aerobic and anaerobic contribution to Wingate test performance in sprint and middle-distance runners. Eur J Appl Phys Occup Phys , 70 (1), 58-65.

Gustin, P. B. (2001). Energy System Interaction and Relative Contribution During Maximal Exercise. Sports Med , 31 (10), 725-41.

Harbili, S. (2015). Relationship between lower extremity isokinetic strength and anaerobic power in weightlifters, basketball and soccer players. Isokinetics and Exercise Science, 23(2), 93-100.

Hazır Aytar, S., Salman, M. N., Devrilmez, E., \& Şatıroğlu, S. (2018). Elit Badmintoncularda Bazı Performans Bileşenleri ve Şampiyona Sıralaması Arasındaki İlişki: Cinsiyetler Arası Karşılaştırma. Hacettepe J of Sport Sci , 29 (1), 27-38.

Kale, M., Aşçı, A., Bayrak, C., \& Açıkada, C. (2009). Relationships among jumping performances and sprint parameters during maximum speed phase in sprinters . J Strength Cond Res , 23 (8), 22748.

Kons, R. L., Ache-Dias, J., Detanico, D., Barth, J., \& Dal Pupo, J. (2018). Is vertical jump height an indicator of athletes' power output in different sport modalities? J Str Cond Res Issue , 32 (3), 70815.

Lockie, R. G., Moreno, M. R., Lazar, A., Orjalo, A. J., Giuliano, D. V., Risso, F. G., et al. (2018). The Physical and Athletic Performance Characteristics of Division I Collegiate Female Soccer Players by Position. J Strength Cond Res , 32 (2), 334-43.

Loturco, I., Winckler, C., Kobal, R., Cal Abad, C. C., Kitamura, K., Verissimo, A. W., et al. (2015). Performance changes and relationship between vertical jump measures and actual sprint performance in elite sprinters with visual impairment throughout a Parapan American games training season. Front Physiol , 6 (323), 1-8.

Mayhew, J. L., Hancock, K., Rollison, L., Ball, T. E., \& Bowen, J. C. (2001). Contributions of strength and body composition to the gender difference in anaerobic power. J Sports Med Phys Fitness , 41 (1), 33-8.

Murphy, A.J., \& Wilson, G.J. (1996). Poor correlations between isometric tests and dynamic performance: relationship to muscle activation. Eur J Appl Physiol Occup Physiol, 73(3-4), 353-7.

Nieman, D. C. (1999). Assessing Body Composition. Human Kinetics.

Owen, A. L., Lago-Penas, C., Dunlop, G., Mehdi, R., Chtara, M., \& Dellal, A. (2018). Seasonal Body Composition Variation Amongst Elite European Professional Soccer Players: An Approach of Talent Identification. J Human Kinetics , 61, 177-84.

Özkan, A., \& Kin-İşler, A. (2010). Sporcularda Bacak Hacmi, Kütlesi, Hamstring/Quadriceps Oranı ile Anaerobik Performans ve İzokinetik Bacak Kuvveti Arasındaki İlişki. Hacettepe Spor Bilimleri Dergisi , 21 (3), 90-102.

Özkan, A., \& Sarol, H. (2008). Dağcılarda Vücut Kompozisyonu, Bacak Hacmi, Bacak Kütlesi, Anaerobik Performans ve Bacak Kuvveti Arasındaki İlişki. SPORMETRE Beden Eğitimi ve Spor Bilimleri Dergisi , 6 (4), 175-81.

Potteiger, J. A., Smith, D. L., Maier, M. L., \& Foster, T. S. (2010). Relationship Between Body Composition, Leg Strength, Anaerobic Power, and On-Ice Skating Performance in Division I Men's Hockey Athletes. J Strength Cond Res , 24 (7), 1755-62.

Saç, A., \& Taşmektepligil, M. (2011). Farklı Sporcu Gruplarında Üç Ayrı Anaerobik Güç Ölçüm Yöntemiyle Elde Edilen Sonuçların Değerlendirilmesi. Spor ve Performans Araştırmaları Dergisi , $2(1), 5-12$.

Sands, W. A., McNeal, J. R., Ochi, M. T., Urbanek, T. L., Jemni, M., \& Stone, M. H. (2004). Comparison of the Wingate and Bosco anaerobic tests. J Strength Cond Res , 18 (4), 810-5.

Silva, A. M. (2018). Structural and functional body components in athletic health and performance phenotypes. Eur J Clin Nutr .

Weyand, P. G., Sternlight, D. B., \& Bellizzi, M. J. (2000). Faster top running speeds are achieved with greater ground forces not more rapid leg movements. J Appl Physiol , 89 (5), 1991-9. 
Wisløff, U., Castagna, C., Helgerud, J., Jones, R., \& Hoff, J. (2004). Strong correlation of maximal squat strength with sprint performance and vertical jump height in elite soccer players. Br J Sports Med, $38,285-8$.

Zupan, M. F., Arata, A. W., Dawson, L. H., Wile, A. L., Payn, T. L., \& Hannon, M. E. (2009). Wingate Anaerobic Test peak power and anaerobic capacity classifications for men and women intercollegiate athletes. J Strength Cond Res , 23 (9), 2598-604.

\section{CITATION OF THIS ARTICLE}

N. Küçükkubaş, N., Günay, A., Löklüoğlu, B., \& Kakil, B. (2019). Relationship Between Body Composition, Vertical Jump, 30 M Sprint, Static Strength and Anaerobic Power for Athletes. Int J Sport, Exer \& Train Sci, 2019, Vol 5, Issue 2, 68-78, doi:10.18826/useeabd.517037 